\title{
Is it Time for a Three-Year Accredited Civil Engineering Degree in the United States? A Critical Review
}

\section{Dr. Brian J. Swenty P.E., University of Evansville}

Brian J. Swenty, Ph.D., P.E. is chair of the Mechanical and Civil Engineering Department at the University of Evansville. He earned his B.S. and Ph.D. degrees from the University of Missouri-Rolla and his M.S. degree in civil engineering from the University of Florida. He is a licensed professional engineer in California, Florida, Missouri, Illinois, and Indiana. He has held positions as an active duty Army officer, a senior civil engineer with a consulting firm, and the director of Missouri's Dam and Reservoir Safety Program. Since 1993, he has been at the University of Evansville, serving as department chair for the past 21 years. He continues to work as a consultant on projects involving the design and construction of new dams, modifications to existing dams, and the investigation of dam failures.

\section{Dr. Matthew Swenty P.E., Virginia Military Institute}

Matthew (Matt) Swenty obtained his Bachelors and Masters degrees in Civil Engineering from Missouri S\&T and then worked as a bridge designer at the Missouri Department of Transportation. He returned to school to obtain his Ph.D. in Civil Engineering at Virginia Tech followed by research work at the TurnerFairbank Highway Research Center on concrete bridges. He is currently an associate professor of Civil Engineering at the Virginia Military Institute (VMI). He teaches engineering mechanics and structural engineering courses at VMI and enjoys working with the students on bridge related research projects and with the ASCE student chapter. 


\title{
Is it Time for a Three-Year Accredited Civil Engineering Degree in the United States? A Critical Review
}

\begin{abstract}
Universities are faced with the increasing challenge of making bachelor degree programs rigorous while making them more affordable and improving graduation rates. One possible approach is to create an accredited, rigorous engineering program that can be completed in less time. Using recently published data on the content of a typical 4-year civil engineering program, a three-year civil engineering curriculum was created and critiqued. This paper evaluates the challenges associated with developing and implementing a three-year civil engineering degree with respect to the new 2019-2020 EAC-ABET criteria, the bachelor degree outcomes in ASCE's Body of Knowledge (BOK3), state licensure laws, and regional accreditation criteria.

The new EAC-ABET Criterion 5 requirements for the 2019-2020 accreditation cycle require 30 credit hours of mathematics and science, 45 credit hours of engineering science, a broad education component, and a culminating engineering design experience. The EAC-ABET criteria do not include a minimum number of years to obtain a degree or a minimum number of credit hours. ASCE's BOK3 is written with the premise that the outcomes should be attained through education and experience. While the BOK3 sets expected levels of achievement through formal education, there is no expectation that all education will come from one source.

A three-year civil engineering degree offers many benefits for students, but creates challenges for state licensure boards, universities, and employers. Benefits include reduced cost and time for students to complete their degree, exposure to civil engineering courses earlier in the curriculum, and program equivalency to Bologna Process universities. Challenges include regional accreditation requirements, reduced breadth in the curriculum, reciprocity of licensure laws, graduate school admissions, and public perception of a three-year civil engineering degree. Comprehensive education and licensure reform would be required to challenge the status quo and implement a three-year degree in civil engineering education.
\end{abstract}




\section{Introduction}

Civil engineering programs are under pressure from many different groups to ensure that curricula address accreditation criteria, the ASCE BOK outcomes, licensure requirements, and state legislature concerns. Yet these groups do not always share common goals. The civil engineering profession wants to maintain robust bachelor degree programs that thoroughly cover engineering fundamentals and include the depth and breadth needed to be a licensed professional engineer. Most engineering licensure boards, groups that are typically under state government control, depend on accreditation organizations to enforce rigorous education standards. Ultimately, public safety is the common thread that connects engineering education to professional engineering licensure and the public. The public and their elected representatives want safe infrastructure, designed and constructed by trustworthy engineers, but they also desire less expensive college education and higher graduation rates [1], [2]. State governments and state legislatures are accountable to constituents who feel the cost of higher education is too expensive [3], [4]. A former university president stated, "Few issues in American higher education today are less well understood yet subject to greater controversy than the price of a college education" [1]. The objective of addressing sometimes conflicting goals is a serious challenge for the civil engineering profession.

The civil engineering profession must respond to the desire for change in higher education. The pressure is mounting and many creative, unique, and counter intuitive methods are likely to come under consideration. This response may take a number of different routes, including reducing the number of engineering credits required for a bachelor's degree, requiring a master's degree for entry into the profession, requiring additional certifications, creating more robust internship experiences, and developing curriculums that are accepted across international borders. By making engineering programs more flexible, has the engineering profession opened the door to creating degree programs that can be completed in less than four years?

One idea that has been implemented in various formats and locations is a three-year degree program. With the increasing demand to justify education content, cost, and success this seems like an appealing option to many, particularly those outside the engineering profession. However, the question remains whether the content of a three-year program can meet accreditation expectations and match the rigor expected by the public and industry. Europeans asked themselves the same question twenty years ago, and interestingly, many of their most prestigious programs now embrace a modified three-year program [3]. As higher education continues to evolve, it behooves the civil engineering profession to consider this option and formulate a response, whether in favor or not, to those who will inevitably ask this question.

There are several well documented factors that influence civil engineering education including the American Society of Civil Engineers (ASCE) Body of Knowledge (BOK), the (Engineering Accreditation Commission) EAC-ABET curriculum and program criteria, and state licensure laws. In addition, the National Council of Examiners for Engineering and Surveying (NCEES) subject areas on the Fundamentals of Engineering (FE) exam influence engineering education indirectly. These factors will continue to advance, develop, and be debated within the engineering profession. The purpose of this study is to critically analyze the feasibility of implementing a three-year civil engineering program that meets EAC-ABET accreditation criteria, BOK3 outcomes, state licensure criteria, and the needs of the profession. 


\section{Background}

In the United States a small number of colleges advertise three-year programs in a variety of majors, although few are engineering. Generally, the programs are accelerated, require more credits during a traditional semester, and require work in the summer. Only the highest performing students are allowed in many of these programs, and they must meet strict entrance requirements. Commonly, this includes entering college with credits already earned toward the degree. Only focused students succeed in these programs, because there is little flexibility in the curriculum to change majors [5], [6]. The tradeoff is worth it to those who want to reduce college expenses and obtain a degree faster.

Some engineering programs have focused on attracting transfer students from other universities. Students can earn a two-year associate's degree at a community college and, when carefully planned, earn an EAC-ABET accredited engineering degree within an additional two years [7]. The key is to earn credits in community college that count toward an engineering degree; this is rarely a seamless transition. A program in Utah was successful because of the close association of community colleges and the University of Utah [8]. However, creating a program like this requires very precise scheduling between the schools. Simply obtaining a pre-engineering associates degree does not guarantee that the credits will count toward the bachelor's degree [9]. Some states (Virginia for example) have extensive community college courses that have preapproved transfer credits in their state university systems. A student who earns an associate's degree with a minimum grade point average gains automatic admission and course credit for most state universities. However, this program does not guarantee that a degree can be completed within two years or any other set period [10]. At the same time, just because a student transfers into a program does not mean they will not succeed in the program. A study in Colorado examined the performance of transfer students compared to traditional four year students over a 10 -year period. The results showed that transfer students have similar grade point averages and do as well as traditional students [11]. While these programs have shown that transferring from community college to a four year program can be accomplished, rarely is it a quick, seamless process for most programs.

Europeans have taken a different approach to making higher education more transparent and efficient in the last twenty years. June 19, 2019 marks the twentieth anniversary of the Bologna Declaration that was approved by the European Ministers of Education at the Ministerial Conference in Bologna, Italy. This common vision for the European Higher Education Area (EHEA) has had a significant impact on higher education in Europe and arguably the world. The Bologna Declaration established a higher education process that was adopted initially by 29 countries [12]. By 2018, a total of 48 countries had signed the accord [13], [14].

Originally, the Bologna Accord was not universally accepted, because programs had to reduce or remove general education requirements and electives to transition to a three-year degree. In many European universities this meant that most of the general education courses had to either be completed prior to matriculation or the universities would have to continue offering a four year degree. Today the majority of European colleges have adopted the Bologna Process to meet government expectations and standardize education in Europe [15], [16]. Just as important, the Bologna Accord has put an additional emphasis on graduate education, a direct intended result. 
Students who want additional depth are encouraged to pursue graduate education for an additional 2 years [17].

The vision articulated by the Bologna Declaration included a number of key elements that were officially adopted at the 2003 Berlin Communique. Two that are germane to this paper are the common European Higher Education Area (EHEA) three-cycle degree system and a common college credit system (ECTS). The degree cycle system corresponds to the United States equivalent of a three-year bachelor's degree, a two-year master's degree, and a three-year doctorate degree (3-2-3). The Bologna Process first cycle (level 6) requires the completion of 180-240 ECTS units in three years [18]. The workload of a full time academic year is equivalent to 60 ECTS units. The assumption is that a full-time academic work load is about 1,500 to 1,800 hours per year which corresponds to about 25 to 30 hours of work per credit hour [19]. By comparison one credit hour in the United States is 45 hours of work [20]. Hence, using these estimates the first cycle degree is equivalent to about 100 credit hours in the United States.

The European equivalent of EAC-ABET is the EUR-ACE® Standards and Guidelines for Accreditation of Engineering Programmes (EAFSG). This standard requires a minimum of 180 ECTS credits or the equivalence of three years of full time study [21]. For the first cycle (bachelors) programs, the accreditation criteria contain outcomes which include: Knowledge and Understanding; Engineering Analysis; Engineering Design; Investigations; Engineering Practice; Making Judgements; Communication and Team-working; and Lifelong Learning. EUR-ACE accredited civil engineering programs must demonstrate that their graduates meet these outcomes, but there are no specific ECTS credit requirements for mathematics, science, or engineering topics as there are in EAC-ABET Criterion 5.

Europe has experienced changes to their education system, but so have undergraduate civil engineering programs in the United States. In the past 16 years, civil engineering programs have changed their curriculums in response to changes in the EAC-ABET criteria, the ASCE Body of Knowledge (BOK), and the transition from a pencil/paper to a computerized FE examination [22]. The number of international engineering programs accredited by EAC-ABET has grown substantially during this period. Yet, EAC-ABET growth has been slow in Europe where higher education has been impacted by the Bologna Process and engineering programs are accredited by EUR-ACE. EAC-ABET has accredited engineering programs in thirty-five countries, seven of which are signatories to the Bologna Process, but there are only two EAC-ABET accredited civil engineering bachelor's degree programs in Europe [23].

\section{Three-Year Civil Engineering Program}

Any curricular changes to an accredited civil engineering program in the United States must meet regional accreditation criteria, EAC-ABET requirements, the needs of the civil engineering profession, and licensure laws and regulations. The program length, whether three, four, or five years of study, is not as important as the program content. The methodology adopted in this research uses the results of a published detailed review of accredited civil engineering curriculums in the United States to develop a three-year, 96 credit hour bachelor's degree in civil engineering. Comparisons are made between this proposed three-year program, the new EACABET Criterion 5, the EAC-ABET civil engineering program criteria, ASCE's draft BOK3, and licensure criteria from twelve jurisdictions in the United States. 
A 2017 comparative study of accredited civil engineering curriculums in the United States indicates that civil engineering programs are offering degrees with an increased level of specialization. During the period 2002 to 2017, the number of elective engineering credit hours in the curriculum increased by $72.7 \%$, from 11.0 to 19.0 , which is now almost $29 \%$ of civil engineering curriculum. Many traditionally required courses such as circuits, thermodynamics, and dynamics are now engineering electives or not required in programs. Since 2002, ASCE's BOK2 outcomes, the EAC-ABET civil engineering program criteria, and the 2014 NCEES changes to the civil engineering FE exam have supported a higher degree of specialization in civil engineering curriculums and a move away from a standardized curriculum [22].

Table 1. Curriculum for a Three-Year Civil Engineering Degree

\begin{tabular}{|c|c|c|c|c|c|}
\hline \multicolumn{2}{|c|}{ Course Curriculum } & \multicolumn{2}{|c|}{ Course Curriculum } & \multirow{2}{*}{$\begin{array}{l}\text { EAC-ABET } \\
\text { Criterion 5* }\end{array}$} & \multirow{2}{*}{$\begin{array}{c}\text { EAC-ABET } \\
\text { CE Program } \\
\text { Criteria** }\end{array}$} \\
\hline 4 year programs [22] & $\begin{array}{l}\text { Credit } \\
\text { Hours }\end{array}$ & 3 year program & $\begin{array}{l}\text { Credit } \\
\text { Hours }\end{array}$ & & \\
\hline Calculus & 11.4 & Calculus & 10.0 & $\mathrm{M} / \mathrm{S}$ & $\mathrm{CE}$ \\
\hline Differential Eqns & 3.2 & Differential Eqns & 3.0 & $\mathrm{M} / \mathrm{S}$ & $\mathrm{CE}$ \\
\hline Probability \& Stats & 3.0 & Probability \& Stats & 3.0 & $\mathrm{M} / \mathrm{S}$ & $\mathrm{CE}$ \\
\hline Physics & 7.3 & Physics & 7.0 & $\mathrm{M} / \mathrm{S}$ & $\mathrm{CE}$ \\
\hline Chemistry & 5.3 & Chemistry & 4.0 & $\mathrm{M} / \mathrm{S}$ & $\mathrm{CE}$ \\
\hline $3^{\text {rd }}$ Natural Science & 3.3 & $3^{\text {rd }}$ Natural Science & 3.0 & $\mathrm{M} / \mathrm{S}$ & $\mathrm{CE}$ \\
\hline Statics & 2.9 & Statics & 3.0 & ET & \\
\hline Dynamics & 2.9 & & & & \\
\hline Solid Mechanics & 3.2 & Solid Mechanics & 3.0 & ET & \\
\hline Fluid Mechanics & 3.5 & Fluid Mechanics & 3.0 & ET & \\
\hline General Education & 21.7 & General Education & 16.0 & & \\
\hline Intro to Engineering & 2.7 & Intro to Engineering & 3.0 & ET & \\
\hline Structural Analysis & 3.3 & Structural Analysis & 3.0 & ET & $\mathrm{CE}$ \\
\hline Soil Mechanics & 3.7 & Soil Mechanics & 4.0 & ET & $\mathrm{CE}$ \\
\hline Transportation Engr & 3.2 & Transportation Engr & 3.0 & ET & $\mathrm{CE}$ \\
\hline Hydraulic Engr & 2.9 & Hydraulic Engr & 3.0 & ET & $\mathrm{CE}$ \\
\hline Environmental Engr & 3.3 & Environmental Engr & 3.0 & ET & $\mathrm{CE}$ \\
\hline Construction Mgt. & 3.0 & & & & \\
\hline CE Materials & 3.0 & CE Materials & 3.0 & ET & $\mathrm{CE}$ \\
\hline Surveying & 2.8 & Surveying & 2.0 & ET & \\
\hline Engr Economics & 2.6 & & & & \\
\hline CE Capstone & 3.9 & CE Capstone & 4.0 & ET & $\mathrm{CE}$ \\
\hline Technical Electives & 11.7 & CE Tech Electives & 12.0 & ET & $\mathrm{CE}$ \\
\hline Computer Aided & 2.3 & & & & \\
\hline Drafting (CAD) & & & & & \\
\hline Other Courses & 12.5 & CE Seminar & 1.0 & & \\
\hline Total Credit Hours & 128.6 & Total Credit Hours & 96.0 & & \\
\hline
\end{tabular}

*EAC-ABET: Engineering Accreditation Commission, ABET, Inc.; M/S - Mathematics and Science; ET - Engineering Topics

** CE: EAC - ABET Civil Engineering Program Criteria 
Because of the diversity in program offerings, curriculum data from the 2017 study were used as a starting point to develop a three-year civil engineering program. Table 1 outlines the results of the 2017 study and a proposed three-year curriculum that meets EAC-ABET Criterion 5 and the EAC-ABET civil engineering program criteria. A close examination of both the EAC-ABET general criteria and the civil engineering program criteria reveals that there are no minimum time requirements for students to complete an accredited civil engineering degree.

The course topics in column one are courses that are currently required in at least $50 \%$ of accredited civil engineering programs in the United States. The credit hour requirements are the average value for each course [22]. The topics in column 3 are the proposed topics for a new three-year civil engineering program. Most three year topics remain at approximately the same number of credit hours as the average four year program. The CE (Civil Engineer) seminar course is designed to cover professional issues in engineering listed in the EAC-ABET civil engineering program criteria including business, public policy, leadership, professional ethics, licensure, and professionalism. Topics that were eliminated include dynamics, construction management, engineering economics, and computer aided drawing (CAD). The topics that saw the biggest reduction in credit hours included general education and "other courses." Other courses included a variety of topics such as free electives, additional civil engineering electives, technical writing, and ROTC.

\section{EAC-ABET Criteria}

In 2017, the Engineering Accreditation Commission (EAC) of ABET approved changes to Criterion 3 and Criterion 5. The changes become effective during the 2019-2020 accreditation cycle. The Criterion 5 changes are notable. Rather than computing the required number of credit hours of mathematics, natural science, and engineering topics as a percentage of a program's total number of credit hours required for a degree, the number of required credit hours is now fixed. The new criteria require 30 credit hours of mathematics and science and 45 credit hours of engineering topics as summarized in Table 2 [24].

The fifth column in Table 1 shows how the three-year civil engineering curriculum meets the math and science requirement (30 credits, labeled $\mathrm{M} / \mathrm{S}$ ) and the engineering topics requirement (50 credits, labeled ET). The proposed credit hours in both categories meet the minimums in EAC-ABET's Criterion 5. The second curriculum requirement in EAC-ABET Criterion 5 is the culminating engineering design experience which is included in the proposed three-year program's Capstone Design course. The third category in Criterion 5 is the broad educational requirements. This category experienced the most significant credit hour reductions in the proposed three-year program. Nonetheless, the 16 credit hour general education component would meet the EAC-ABET requirements.

The EAC-ABET civil engineering program criteria are summarized in Table 3 . There are specific requirements for mathematics, natural sciences, civil engineering technical areas, design content, experimentation, sustainability, and a series of other topics related to business, management, public policy, leadership, professional ethics, and licensure. Every civil engineering program has the discretion to determine how they will meet these criteria. 
A minimum of 30 semester credit hours (or equivalent) of a combination of college-level mathematics and basic sciences with experimental experience appropriate to the program.

A minimum of 45 semester credit hours (or equivalent) of engineering topics appropriate to the program, consisting of engineering and computer sciences and engineering design, and utilizing modern engineering tools.

A broad education component that complements the technical content of the curriculum and is consistent with the program educational objectives.

A culminating major engineering design experience that 1) incorporates appropriate engineering standards and multiple constraints, and 2) is based on the knowledge and skills acquired in earlier course work.

Each program determines the degree requirements, including the total number of credit hours, the number of required civil engineering courses, the number of technical elective courses, and the organization of the design courses. Table 1 column 6 demonstrates how all of these civil engineering program criteria could be met with the proposed 3 year engineering curriculum. The reality is there are very few differences in the engineering, mathematics and science requirements between the 3 year program and current 4 year civil engineering programs. The primary differences are credit hour reductions in the general education and elective categories. A close examination of both the EAC-ABET general criteria and the civil engineering program criteria reveals that there are no minimum time requirements for students to complete an accredited civil engineering degree.

Table 3. 2019-2020 EAC-ABET Civil Engineering Program Criteria [24]

\begin{tabular}{ll}
\hline $\begin{array}{l}\text { Program } \\
\text { Criteria }\end{array}$ & Civil Engineering \\
& Mathematics through differential equations \\
& Calculus-based Physics \\
& Chemistry \\
& Basic science in a $3^{\text {rd }}$ area \\
& Probability and statistics to address uncertainty \\
& At least 4 technical areas appropriate to Civil Engineering \\
& Conduct experiments in at least 2 Civil Engineering areas \\
& Design in at least 2 Civil Engineering contexts \\
& Sustainability in design \\
& Basic Concepts: project management, business, public policy, leadership \\
& Professional ethics \\
& Professional licensure \\
\hline
\end{tabular}




\section{ASCE Body of Knowledge}

One of the challenges of implementing a three-year, 96-credit hour civil engineering curriculum is satisfying the needs of the civil engineering profession in terms of ASCE's updated Body of Knowledge (BOK3). The draft BOK3 reduced the number of outcomes in the BOK2 from 24 to 21. The BOK3 outcomes and their relationship to a three-year civil engineering curriculum are summarized in Table 4. The BOK3 outcomes are assembled in four categories: foundational, technical, engineering fundamentals, and professional [25].

The educational component of eighteen of the twenty-one BOK3 outcomes would be included in the three-year civil engineering curriculum shown in Table 1. Three of the BOK3 outcomes, material science, project management, and engineering economics, would have to be met with elective courses or integrated in other required courses. Although materials science was listed as a BOK2 outcome and is listed as a BOK 3 outcome, less than $10 \%$ of accredited civil engineering curriculums currently require students to take a materials science course [22]. To fulfill the BOK3 project management and engineering economics outcomes, students would either have to take these courses using technical elective credit, obtain knowledge from other required courses, or meet the expectations through experience and independent learning. The BOK3 professional outcomes $18,19,20$, and 21 would be covered in a civil engineering seminar course or through professional experience.

\begin{tabular}{|c|c|c|c|}
\hline BOK3 & Outcomes & Category & $\begin{array}{l}\text { Included in 3-Year } \\
\text { CE Curriculum }\end{array}$ \\
\hline 1 & Mathematics & \multirow{4}{*}{ Foundational } & Calculus, Differential Equations \\
\hline 2 & Natural Sciences & & Physics, Chemistry, $3^{\text {rd }}$ Science \\
\hline 3 & Social Sciences & & General Education Courses \\
\hline 4 & Humanities & & General Education Courses \\
\hline 5 & Materials Science & \multirow{4}{*}{$\begin{array}{l}\text { Engineering } \\
\text { Fundamentals }\end{array}$} & \\
\hline 6 & Engineering Mechanics & & Statics, Mechanics of Materials \\
\hline 7 & Experiment Methods and Data Analysis & & CE Lab Courses in two CE areas \\
\hline 8 & Critical Thinking and Problem Solving & & Required CE Courses \\
\hline 9 & Project Management & \multirow{7}{*}{ Technical } & \\
\hline 10 & Engineering Economics & & \\
\hline 11 & Risk and Uncertainty & & Probability and Statistics \\
\hline 12 & Breadth in Civil Engineering Areas & & Four CE Areas Required \\
\hline 13 & Design & & Capstone Design Course \\
\hline 14 & Technical Depth & & Technical Electives \\
\hline 15 & Sustainability & & Required CE Courses \\
\hline 16 & Communication & \multirow{6}{*}{ Professional } & Capstone Design Course \\
\hline 17 & Teamwork and Leadership & & Capstone Design Course \\
\hline 18 & Lifelong Learning & & CE Seminar \\
\hline 19 & Professional Attitudes & & CE Seminar \\
\hline 20 & Professional Responsibilities & & CE Seminar \\
\hline 21 & Ethical Responsibilities & & CE Seminar \\
\hline
\end{tabular}


The draft BOK 3 refers to two educational domains, the cognitive domain and the affective domain. The level of achievement in the cognitive domain for the three-year, 96-credit hour civil engineering curriculum would vary among the categories, but this is no different than the variations that currently exist in four year civil engineering programs. The outcomes are obtained through a combination of education and experience. ASCE is explicit in pointing out that the BOK 3 outcomes cannot be fulfilled through education alone. Meeting the outcomes involves being mentored by practicing engineers, gaining early career experience, participating in self-developed learning, and obtaining additional formal education [25].

\section{Professional Licensure}

ASCE's Policy 465 advocates that entry into the civil engineering profession as a licensed engineer would happen after obtaining a master's degree or 30 additional credit hours [26]. This position was supported by NCEES in 2006 , but has not been adopted by any state licensure board in the United States.

Table 5. Education Requirements for State Licensure

\section{State Education Requirements for Professional Engineering Licensure} (State Code Reference)

\begin{tabular}{|c|c|}
\hline Arizona & $\begin{array}{l}\text { Combination of } 8 \text { years of experience and education; maximum of } 5 \text { years of } \\
\text { education; no minimum education requirement }(32-122-01)\end{array}$ \\
\hline California & $\begin{array}{l}\text { Six years of education plus experience, up to five years of which can be post- } \\
\text { secondary education; no minimum education requirement (Article } 4,6751 \text { ) }\end{array}$ \\
\hline Florida & $\begin{array}{l}\text { Graduate of an approved engineering curriculum of four years or more and four years } \\
\text { or more of qualifying experience (Title XXXII, Chapter 471.013) }\end{array}$ \\
\hline Illinois & $\begin{array}{l}\text { Graduate of an approved engineering curriculum of four years or more (minimum } 120 \\
\text { cr hr, Title } 68 \text {, Chapter VII, subchapter b, section 1380.210) and four years or more of } \\
\text { qualifying experience ( } 225 \text { ILCS } 325 / 10 \text { ) }\end{array}$ \\
\hline Indiana & $\begin{array}{l}\text { Graduate of an approved engineering curriculum of four years or more and four years } \\
\text { or more of qualifying experience or eight years of education and experience (IC 25- } \\
31-1-12 \text { ) }\end{array}$ \\
\hline Missouri & $\begin{array}{l}\text { Baccalaureate degree in engineering from an accredited school of engineering and } \\
\text { four years of approved experience (Section 327.221 RSMo) }\end{array}$ \\
\hline New York & $\begin{array}{l}\text { Bachelor's degree in engineering and at least four years of satisfactory experience or } \\
\text { twelve years of approved experience with up to two years credit for engineering } \\
\text { education (Article 145, Section 7206) }\end{array}$ \\
\hline Ohio & $\begin{array}{l}\text { Graduate of a non-accredited engineering curriculum of four years or more and eight } \\
\text { years of experience ( } 4733.11 \text { Ohio Revised Code) }\end{array}$ \\
\hline Pennsylvania & $\begin{array}{l}\text { Graduate of an approved engineering curriculum of four years or more and four or } \\
\text { more years of progressive experience after passing the FE exam or twelve years of } \\
\text { approved experience up to four years credit for engineering education (Section } 4.2 \text {, } \\
\text { P.L. } 782 \text {, No. 192) }\end{array}$ \\
\hline Tennessee & $\begin{array}{l}\text { Graduate of an approved engineering curriculum of four years or more and four or } \\
\text { more years of progressive experience }(62-2-401)\end{array}$ \\
\hline Texas & $\begin{array}{l}\text { Graduate of a board approved degree and four years or more of qualifying experience } \\
\text { or graduate of a non-accredited degree and eight years of experience; no minimum } \\
\text { number of years specified for either degree (Title } 6 \text {, Subtitle A, Chapter 1001.302) }\end{array}$ \\
\hline Wyoming & $\begin{array}{l}\text { Graduate of an accredited engineering curriculum of four years or more and four } \\
\text { years or more of qualifying experience }(33-29-403)\end{array}$ \\
\hline
\end{tabular}




\section{Regional Accreditation Criteria}

There are seven regional accreditation organizations in the United States that are recognized by the Council for Higher Education Accreditation (CHEA) [27]. The accreditation criteria for two of these regional accreditation organizations, the Higher Learning Commission (HLC) and the Southern Association of Colleges and Schools (SACS) were examined; together these two organizations accredit universities in 30 of the 50 states. HLC conforms to a commonly accepted minimum bachelor's degree consisting of 120 credit hours, but allows universities to explain and justify variations from this number [28]. Likewise, SACS requires "at least 120 semester credit hours or equivalent at the baccalaureate level" but provides universities the opportunity to justify degree programs that include fewer than the required number of semester credit hours [29]. Obtaining regional accreditation for a three-year, 96-credit hour civil engineering curriculum would require a university to provide justification for the change and request a curriculum variance for the 120 credit hour requirement.

\section{Graduate School Acceptance of Three-Year Engineering Degrees}

Duration of engineering education has historically been linked to quality and rigor. Many in the United States are still skeptical of whether a three-year Bologna degree is equivalent to a four year accredited degree in the United States [13], [30]. The question is whether duration or benchmarking is the key component of a quality education [31]. This issue is addressed by universities when considering applications to graduate schools [30].

Some engineering graduate programs in the United States accept students with three-year Bologna bachelor's degrees directly into their programs. Admission into graduate school is a unique process among universities and even among different programs at the same university. There are numerous components that are taken into account in addition to educational background that include experience, recommendations, and essays [31]. A cursory search of institutional websites revealed that some U.S. institutions accept the three-year Bolognacompliant bachelor's degree for graduate admission, some accept the degree but require completion of a one-year bridge program, and some accept the degree but also place emphasis on GPA and performance on GRE/GMAT exams in their final admission decision [13], [32].

Because of the non-uniform nature of the process, there is not a national standard addressing three-year Bologna degree's for admission into U.S. graduate programs. Yet, there is evidence that Bologna students have performed well in U.S. graduate programs [30].

\section{Discussion}

Civil engineering programs in the United States have traditionally required in excess of 120 credit hours to obtain a degree [22]. The benefits and challenges associated with reducing this to a three-year civil engineering degree are summarized in Table 6.

A three-year accredited civil engineering degree would align engineering degrees in the United States with engineering degrees in Europe and other parts of the world. The degree would be less expensive and would enable students to graduate and enter the work force earlier. A possible side effect of a three-year civil engineering degree is the creation of a "tiered system" within the profession similar to physician assistants (PA) and physicians in the medical profession. The civil engineering profession has historically been challenged with the question of whether to 
allow engineering technology graduates to take the P.E. exam. A three-year degree may further complicate the division of labor within the civil engineering profession.

Table 6. Three Year Civil Engineering Degree: Benefits and Challenges

\begin{tabular}{ll}
\hline Benefits & $\begin{array}{l}\text { Lower Cost } \\
\text { Less Time to Complete a CE degree } \\
\text { Exposure to CE courses earlier in the curriculum and better } \\
\text { academic preparation for internships }\end{array}$ \\
Alignment with international standards for three-year CE degrees and \\
increased global mobility
\end{tabular}

American University and Vanderbilt have programs that allow business and political science students to complete bachelor's degrees in three years and use a fourth year to complete a master's degree [5]. By reducing the civil engineering bachelor's degree to three years, students may take advantage of programs that would allow them to obtain a master's degree in an additional 1-2 years. This may be a method of encouraging students to pursue graduate education to become licensed sooner or simply to obtain more depth of knowledge in their discipline. In essence, by streamlining the bachelor's degree, the civil engineering profession could raise the bar for entry at the professional level [26].

\section{Conclusion}

A three-year, 96-credit hour civil engineering curriculum was developed to meet the new EACABET Criterion 5 and the EAC-ABET civil engineering program criteria. The curriculum includes 30 credit hours of mathematics and science, 50 credit hours of engineering topics, and 16 credit hours of general education courses.

The three-year civil engineering curriculum would meet the educational component of eighteen of the twenty-one ASCE BOK3 outcomes. Three of the BOK3 outcomes: material science, project management, and engineering economics, would have to be met with technical elective classes.

State licensure laws and regulations were examined in a sample of twelve states. Graduates of an accredited three year civil engineering program would be required to obtain post-graduate education in six of the states to qualify to take the NCEES Principles and Practice of Engineering 
(PE) examination. To allow graduates of a three-year civil engineering degree to be licensed, many state licensure boards would have to modify their degree definitions, education criteria, reciprocity criteria, and possibly require a graduate degree or additional credit hours to take the PE exam.

Accreditation criteria were reviewed in two regional accreditation organizations that accredit institutions in 30 of the 50 states. Both organizations require a minimum of 120 credit hours to obtain a bachelor's degree, but both provide institutions the opportunity to justify offering bachelor's degrees with a fewer number of credit hours. Any institution seeking to develop and implement a three-year bachelor's degree in civil engineering would have to justify the change and obtain approval from their regional accreditation organization.

The three-year civil engineering program would meet the EAC-ABET criteria for accreditation and would include the educational component of most BOK3 topics, but changes to state licensure laws and regulations would pose the most significant challenge to implementation. Recent changes to the EAC-ABET accreditation criteria have removed many of the curriculum hurdles that would prevent a three-year civil engineering degree program from becoming a reality. The civil engineering profession must decide whether this is a reasonable route forward or a step backward. A three-year degree could be a unique, unconventional way of changing the civil engineering degree paradigm. The three-year engineering degree deserves serious consideration and critique in an era when constituents are questioning the structure of higher education.

\section{References}

[1] L. Lapovsky, "Tuition Reset: An Analysis of Eight Colleges that Addressed the Excalating Price of Higher Education," Lapovsky Consulting, Longboat Key, FL, $2015 .$.

[2] National Center for Education Statistics, "Digest of Education Statistics," December 2017. [Online]. Available:

https://nces.ed.gov/programs/digest/d17/tables/dt17_326.10.asp. [Accessed 9 January 2019].

[3] W. Marshall and P. Weinstein, "Why We Need the 3-Year College Degree," 26 August 2015. [Online]. Available: www.cnn.com. [Accessed 22 September 2018].

[4] A. Ripley, "Why Is College in America So Expensive?," 11 September 2018. [Online]. Available: https://www.theatlantic.com/education/archive/2018/09/why-is-college-soexpensive-in-america/569884/. [Accessed 9 January 2019].

[5] K. Hopkins, "New Three-Year Degree Programs Trim College Costs," 29 February 2012. [Online]. Available: www.usnews.com/education. [Accessed 22 November 2018]. 
[6] A. R. Kukreti, T. C. Keener, P. L. Bishop and S. T. Kowel, "The Accelerated Engineering Degrees (ACCEND) Program in Civil and Environmental Engineering at the University of Cincinnati," in ASEE Annual Conference Proceedings, 2003.

[7] K. R. Leitch and E. B. Butler, "Creating a New Civil Engineering Program in the 21st Century," in IEEE Frontiers in Education Conference, 2015.

[8] N. M. Safai and L. Reaveley, "Universal Model - A Partnership for an Accelerated Civil Engineering Program Bridging the Civil Engineering Education from the Community College to a University," in ASEE Annual Conference and Exposition, 2005.

[9] C. M. Wigal and T. MeGhee, "Developing an Effective Community College Transfer Pre-Engineering Program," in ASEE Annual Conference and Exposition, Conference Proceedings, 2011.

[10] Virginia's Community Colleges, "Guranteed Transfer," April 2018. [Online]. Available: http://www.vccs.edu/students/transfers/. [Accessed 16 January 2019].

[11] M. Mincie, "Transfer Success of Civil Engineering Technology Degree Community College Graduates to a Bachelor Degree Civil Engineering Technology Program," in ASEE Annual Conference and Exposition, 2008.

[12] European Higher Education Area, "Bologna Process History," European Higher Education Area, 10 January 2019. [Online]. Available:

http://www.ehea.info/pid34248/history.html. [Accessed 10 January 2019].

[13] J. Stannard, "Evaluating Three-Year Degrees from Europ: Why Is This Still an Issue?," IEM Spotlight Newsletter, VOL 14, August 2017. [Online]. Available: www.nafsa.org. [Accessed 22 September 2018].

[14] European Commission/EACEA/Eurydice, "The European Higher Education Area in 2018: Bologna Process Implementation Report," Publications Office of the European Union, Luxembourg, 2018.

[15] A. Usher, "A European Perspective on Three-Year Degrees," 11 March 2014. [Online]. Available: http://higheredstrategy.com. [Accessed 22 September 2018].

[16] A. M. Koenig, S. Bernhard and E. Spark, "AACRAO International Activities on Bologna-Compliant Three-Year Degrees," 11-14 April 2018. [Online]. Available: nagap.org. [Accessed September 2018].

[17] D. J. Bennett, "Institutional Strategies for Addressing Three-Year Degrees: Bologna and 
Beyond," in Council of Graduate Schools 49th Annual Meeting, San Franciso, 2009.

[18] C. Neal-Sturgess, "Bologna and the MEng: 'Sleepwalking into Unknown and Unpredictable Territory'," International Journal of Electrical Engineering Education, pp. 129-138, 1 April 2007.

[19] European Commission, "ECTS Users' Guide," Publications Office of the European Union, Luxembourg, 2015.

[20] "Electronic Code of Federal Regulations," U.S. Government Publishing Office, 20 December 2018. [Online]. Available: https://www.ecfr.gov/cgi-bin/textidx?rgn= $\operatorname{div} 8 \&$ node $=34: 3.1 .3 .1 .1 .1 .23 .2$. [Accessed 9 January 2019].

[21] European Network for Accreditation of Engineering Education (ENAEE), "Standards and Guidelines for Accreditation of Engineering Programmes," ENAEE, 9 January 2019. [Online]. Available: https://www.enaee.eu/accredited-engineering-courseshtml/engineering-schools/accredited-engineering-programs/. [Accessed 9 January 2019].

[22] B. J. Swenty and M. K. Swenty, "The Impact of EAC-ABET Program Criteria on Civil Engineering Curricula," in ASEE Annual Conference and Exposition, Salt Lake City, UT, 2018.

[23] ABET, Inc, "ABET-Accredited Programs," ABET, Inc., 11 January 2019. [Online]. Available: http://main.abet.org/aps/Accreditedprogramsearch.aspx. [Accessed 11 January 2019].

[24] EAC-ABET, "Criteria for Accrediting Engineering Programs," ABET, Inc., Baltimore, MD, 2018.

[25] American Society of Civil Engineers, "Civil Engineering Body of Knowledge - Third Edition," ASCE Press, Reston, VA, 2018.

[26] American Society of Civil Engineers, "ASCE Policy 465," 17 March 2017. [Online]. Available: https://www.asce.org/issues-and-advocacy/public-policy/policy-statement465---academic-prerequisites-for-licensure-and-professional-practice/. [Accessed 5 January 2019].

[27] Council for Higher Education Accreditation, "Regional Accrediting Organizations," 11 March 2019. [Online]. Available: https://www.chea.org/regional-accreditingorganizations. [Accessed 11 March 2019].

[28] Higher Learning Commission, "HLC Policy Book," November 2018. [Online]. 
Available: http://download.hlcommission.org/policy/HLCPolicyBook_POL.pdf. [Accessed 1 March 2019].

[29] Southern Association of Colleges and Schools, "The Principles of Accreditation," December 2017. [Online]. Available:

http://www.sacscoc.org/pdf/2018PrinciplesOfAcreditation.pdf. [Accessed 1 March 2019].

[30] F. S. Report, "The U.S. Perspective on the Three-Year Bologna-Compliant Bachelor's Degree," AACRAO International, Washington, 2017.

[31] J. Saidi-Kuchnert, "The Three-Year Bologna Bachelor's Degrees: A U.S. and European Perspective," ACEI-Global, 14 July 2017. [Online]. Available: https://acei-global.blog. [Accessed 15 September 2018].

[32] M. Gottlieb, J. Saidi-Kuehnert and A. B. Pedersen, "A Report on the Three-Year Bologna Bachelor's Degrees Presentation at the ENIC-NARIC Meeting in Copenhagen, Denmark," NAFSA, August 2017. [Online]. Available: https://www.nafsa.org/Professional_Resources/Browse_by_Interest/International_Studen ts_and_Scholars/Network_Resources/International_Enrollment_Management/A_Report_ on_the_ThreeYear_Bologna_Bachelor\%E2\%80\%99s_Degrees_Presentation_at_the_ENICNARIC_Meeting_. [Accessed 15 January 2018].

[33] A. Anwar and D. Richards, "The Washington Accord and U.S. Licensing Boards," Journal of Professional Issues in Engineering Education and Practice, vol. 141, no. 4, pp. 1-15, 2015.

[34] M. K. Swenty and B. J. Swenty, "Professional Licensure: The Core of the Civil Engineering Body of Knowledge," in ASEE Annual Conference and Exposition, Columbus, OH, 2017. 